\title{
Complement Component Gene
}

National Cancer Institute

\section{Source}

National Cancer Institute. Complement Component Gene. NCI Thesaurus. Code C21518.

These genes encode more than 30 proteins of the complement system engaged in host defense. This system provides both an independent immune system capable of attacking microbes as well as other foreign material and an adjunct to the antibody system. Once activated, the complement system fires in a cascade-like fashion in which one component activates the next. Both swift and powerful, millions of complement components can deposit on an invading microbe within only a few minutes. Such a potent system requires strict regulation to avoid host injury. Membrane cofactor protein (MCP) is one critical regulator aimed at controlling inadvertent complement activation on host cells and nearly every cell examined expresses MCP on its cell membrane. 